\title{
Efektivitas Pupuk Daun terhadap Pertumbuhan dan Hasil Kedelai pada Sistem Tanpa Olah Tanah
}

\author{
Dewi Auliya Ulva1), Supriyono ${ }^{1 *}$, Pardono1)
}

\begin{abstract}
Maintaining soil quality can be done by cultivating soybean using the conservation soil tillage principle, which can be applied in no tillage soil system. The purpose of this study was to obtain the influence of the type of leaf fertilizer and the frequency of leaf fertilizer application on the growth and yield of soybeans in the without tillage system. This research was conducted in Kedawung, Sragen Central Java on May-August 2018. The research used randomized complete block design (RCBD) with 7 levels and 4 replications. Foliar fertilizer was given every 10 and 15 days. The observed variables were periodic observations, maximum vegetative, and yield. Maximum vegetative and periodic observations showed that P3 (gandasil D fertilizer every 15 days) has significant effect and resulted the highest yield. The results of the study showed that gandasil $D$ fertilizer every 15 days treatment increased leaf area index. Gandasil b every 15 days treatment increased the yield of 100 seeds, but reduce the quantity of seed weight/plot, and foliar fertilizer is not effectively used in this cultivation.
\end{abstract}

Keywords: Generative Foliar Fertilizer, Paddy, Vegetative.

\section{PENDAHULUAN}

Kedelai merupakan salah satu komoditas tanaman pangan yang memiliki peran penting dalam peningkatan gizi masyarakat Indonesia. Kedelai juga memiliki peran penting didalam pertanian berkelanjutan dan ekonomi negara (Zhao et al. 2017). Produksi kedelai nasional tahun 2009 mencapai 974,512 ton, pada tahun 2015 mengalami penurunan menjadi 963,183 ton (BPS 2016). Rendahnya produksi kedelai Indonesia salah satunya dikarenakan degradasi lahan dan penggunaan pupuk yang kurang tepat (Adnan et al. 2012).

Usaha mempertahankan kualitas tanah tetap baik dalam teknik budidaya kedelai dapat menggunakan prinsip olah tanah konservasi (OTK) yang salah satunya adalah sistem TOT. Sistem TOT mampu mempertahankan porositas struktur tanah, mengurangi kehilangan tanah karena erosi, dan mengurangi tingkat evaporasi (Mastutik et al. 2013). Selain itu upaya penambahan unsur hara terhadap kedelai pada sistem TOT, hanya diperbolehkan melalui pertanaman sebelumnya dan pemberian pupuk melalui bagian tanaman (daun).

Kedelai membutuhkan nitrogen yang lebih dominan dibandingkan unsur dan senyawa lain pada masa pertumbuhannya (Yinbo Gan et al. 2010). Selain itu upaya penambahan unsur hara terhadap kedelai pada sistem TOT, hanya diperbolehkan melalui pertanaman sebelumnya dan pemberian pupuk melalui bagian tanaman (daun). Salah satu cara yang dilakukan dengan pemberian pupuk daun Gandasil B pada fase generatif dan Gandasil D pada fase vegetatif yang dapat mendorong dan meningkatkan pembentukan klorofil daun (Taufika 2011). Tujuan penelitian ini untuk mendapatkan pengaruh jenis pupuk daun dan frekuensi pemberian pupuk daun terhadap pertumbuhan dan hasil kedelai pada sistem TOT.

1) Program Studi Agroteknologi, Fakultas Pertanian, Universitas Sebelas Maret Surakarta

*Author Contact : supriyono_uns@yahoo.com

\section{BAHAN DAN METODE}

Penelitian ini dilaksanakan di Desa Celep, Kedawung, Sragen pada Mei-Agustus 2018. Suhu rata-rata pada lokasi penelitian yaitu $27^{\circ} \mathrm{C}$. Kelembapan udara sebesar $84 \%$. Kondisi tanah pda lahan tersebut mengandung unsur hara $\mathrm{N}$ total $0.27 \%$ (sedang), $\mathrm{P}_{2} \mathrm{O}_{5}$ sebesar $15.61 \mathrm{ppm}$ (sangat tinggi), $\mathrm{K}_{2} \mathrm{O}$ sebesar 0.32 $\mathrm{Me} \%$ (sedang), C organik sebesar $1.59 \%$ (rendah), bahan organic sebesar $2.74 \%$ (sedang), dan $\mathrm{C} / \mathrm{N}$ ratio sebesar 5.89 (rendah) dengan pH sebesar 6.78 (netral).

Bahan yang digunakan pada penelitian ini meliputi benih kedelai varietas Anjasmoro, pupuk daun Gandasil D 100 gram, pupuk daun Gandasil B 100 gram, sedangkan alat yang digunakan meliputi tugal, ajir, cangkul, plastik ukuran $1.6 \times 1.4 \mathrm{~m}$. Penelitian dilakukan dengan menggunakan Rancangan Acak Kelompok Lengkap (RAKL) satu faktorial, yang terdiri dari 7 perlakuan dan 4 kali ulangan. Perlakuan terdiri dari: P1 (kontrol), P2 (pupuk Gandasil D 10 hari), P3 (pupuk Gandasil D 15 hari), P4 (pupuk Gandasil B 10 hari), P5 (pupuk Gandasil B15 hari), P6 (pupuk Gandasil D dan B 10 hari), P7 (pupuk Gandasil D dan B 15 hari).

Variabel pengamatan meliputi tinggi tanaman, jumlah daun, warna daun, diameter batang, indeks luas daun, jumlah polong per tanaman, berat 100 biji, jumlah biji per polong, berat biji per petak, berat segar brangkasan, berat kering brangkasan. Data yang diperoleh dianalisis menggunakan tabel sidik ragam (a $=5 \%$ ). Hasil sidik ragam yang berpengaruh nyata (signifikan) kemudian dilanjutkan dengan uji DMRT, taraf kepercayaan $95 \%$.

\section{HASIL DAN PEMBAHASAN}

Pemberian pupuk daun mampu meningkatkan tinggi tanaman kedelai (Tabel 1). Perlakuan P3 (pupuk daun Gandasil D setiap 15 hari) dapat meningkatkan tinggi tanaman paling besar dibandingkan perlakuan yang lain, karena dapat memenuhi kebutuhan nitrogen tanaman, dan adanya peneyerapan yang baik. Unsur hara $\mathrm{N}$ berperan penting pada fase vegetatif tanaman. Tanaman yang tumbuh lebih tinggi memungkinkan 
tanaman untuk lebih mampu berkompetisi mendapatkan sinar matahari untuk tumbuh dan berkembang dengan baik.

Tabel 1. Rerata tinggi kedelai dengan berbagai perlakuan

\begin{tabular}{|c|c|c|c|c|c|}
\hline \multirow[b]{2}{*}{ Gandasil } & \multicolumn{5}{|c|}{ Minggu Ke - } \\
\hline & $\begin{array}{l}\text { Frekuensi } \\
\text { Aplikasi }\end{array}$ & 1 & 2 & 3 & 4 \\
\hline Tanpa pupuk & - & 16,58 & 19,50 & 28,92 & 50,25 \\
\hline D & 10 hari & 16,30 & 17,98 & 28,21 & 51,85 \\
\hline D & 15 hari & 16,68 & 18,63 & 31,47 & 53,15 \\
\hline B & 10 hari & 16,60 & 18,65 & 27,47 & 46,06 \\
\hline B & 15 hari & 16,01 & 15,55 & 28,35 & 44,95 \\
\hline$D, B$ & 10 hari & 14,78 & 15,55 & 24,01 & 38,95 \\
\hline $\mathrm{D}, \mathrm{B}$ & 15 hari & 15,17 & 17,03 & 24,55 & 39,68 \\
\hline
\end{tabular}

Menurut Fiyanti dan Prasasti (1991), kandungan nitrogen yang terserap pada daun mampu merangsang pertumbuhan akar, batang, dan daun tanaman kedelai. Pupuk akan segera diabsorbsi dan respon tanaman dapat terlihat dalam dua hari atau tiga hari. Menurut Mandie et al. (2015), pemberian pupuk melalui daun memberikan respon yang cepat tetapi bersifat sementara sehingga pemberiannya harus berulang. Pemenuhan unsur hara melalui pemupukan daun dapat meningkatkan laju fotosintesis. Peningkatan laju fotosintesis dapat memicu pertumbuhan tanaman khususnya tinggi tanaman.

Jumlah daun tanaman kedelai selama pertumbuhan, juga mengalami peningkatan sesuai dengan adanya pertambahan umur tanaman (Tabel 2). Peningkatan jumlah daun terjadi mulai minggu ke 1 hingga minggu ke 4. Hal tersebut menunjukkan kedelai memiliki pertumbuhan yang baik.

Tabel 2. Rerata jumlah daun kedelai dengan berbagai perlakuan

\begin{tabular}{llcccc}
\hline \multicolumn{5}{c}{ Minggu Ke - } \\
\hline Gandasil & $\begin{array}{l}\text { Frekuensi } \\
\text { Aplikasi }\end{array}$ & 1 & 2 & 3 & 4 \\
\hline Tanpa pupuk & - & 2,58 & 5,83 & 7,58 & 9,75 \\
D & 10 hari & 3,00 & 5,66 & 7,25 & 10,25 \\
D & 15 hari & 3,00 & 6,41 & 7,83 & 11,25 \\
B & 10 hari & 2,66 & 4,75 & 6,75 & 9,73 \\
B & 15 hari & 2,25 & 4,58 & 6,75 & 8,50 \\
D dan B & 10 hari & 2,66 & 4,66 & 6,41 & 8,00 \\
D dan B & 15 hari & 2,33 & 4,91 & 6,75 & 7,66 \\
\hline
\end{tabular}

Hasil jumlah daun tertinggi ditunjukkan perlakuan P3 (pupuk daun Gandasil D setiap 15 hari) yaitu 11.25 helai. Jumlah daun terendah ditunjukkan P7 (pupuk daun Gandasil D dan B setiap 15 hari). Hal tersebut diduga perlakuan $\mathrm{P} 7$ tidak dapat menyerap unsur hara dengan baik. Menurut Rosmawati dan Nasruddin (2011), pupuk daun memiliki sifat suplai hara hanya sementara, sehingga jika cairan yang menempel di permukaan daun habis, maka suplai haranya berhenti. Kecepatan hilangnya cairan tersebut dipengaruhi oleh faktor lingkungan seperti intensitas cahaya dan suhu. Semakin tinggi intensitas cahaya pada suatu tanaman, maka hilangnya cairan pupuk daun akan semakin cepat.

Indikator lain yang dapat menunjukkan pertumbuhan kedelai adalah diameter batang, indeks luas daun, dan warna daun yang diamati saat vegetative maksimum. Pemberian pupuk daun berpengaruh dan berbeda nyata terhadap indeks luas daun (ILD) kedelai (Tabel
3). Hal tersebut menunjukkan bahwa pupuk daun memiliki pengaruh dalam pertumbuhan kedelai. P3 (pupuk Gandasil D setiap 15 hari) memiliki ILD tertinggi yaitu 7.59. Pengaruh tersebut karena tercukupinya unsur hara nitrogen pada kedelai. Booij et al. (1996), menyampaikan bahwa nitrogen merupakan faktor penting yang mempengaruhi ILD tanaman, pada fase awal pertumbuhan tanaman.

Tabel 3. Pengaruh pupuk daun terhadap variabel vegetatif maksimum kedelai

\begin{tabular}{lllll}
\hline \multicolumn{5}{c}{ Variabel Pengamatan } \\
\hline Gandasil & $\begin{array}{c}\text { Frekuensi } \\
\text { Aplikasi }\end{array}$ & $\begin{array}{l}\text { Diamter } \\
\text { Batang }(\mathrm{cm})\end{array}$ & $\begin{array}{l}\text { Indeks Luas } \\
\text { Daun }(\mathrm{cm})\end{array}$ & $\begin{array}{c}\text { Warna } \\
\text { Daun }\end{array}$ \\
\hline Tanpa pupuk & - & $0,44 \pm 0,02 \mathrm{ab}$ & $4,10 \pm 0,32 \mathrm{~b}$ & $1,50 \pm 0,58 \mathrm{ab}$ \\
D & 10 hari & $0,56 \pm 0,04 \mathrm{~b}$ & $4,94 \pm 0,81 \mathrm{~b}$ & $1,25 \pm 0,50 \mathrm{a}$ \\
D & 15 hari & $0,56 \pm 0,05 \mathrm{~b}$ & $7,59 \pm 1,16 \mathrm{c}$ & $1,75 \pm 0,50 \mathrm{ab}$ \\
B & 10 hari & $0,48 \pm 0,04 \mathrm{ab}$ & $4,38 \pm 1,57 \mathrm{~b}$ & $2,00 \pm 0,82 \mathrm{ab}$ \\
B & 15 hari & $0,49 \pm 0,03 \mathrm{ab}$ & $3,60 \pm 0,77 \mathrm{ab}$ & $2,75 \pm 1,50 \mathrm{~b}$ \\
D,B & 10 hari & $0,47 \pm 0,09 \mathrm{ab}$ & $2,55 \pm 0,76 \mathrm{a}$ & $2,50 \pm 0,58 \mathrm{ab}$ \\
D,B & 15 hari & $0,39 \pm 0,03 \mathrm{a}$ & $2,33 \pm 0,53 \mathrm{a}$ & $1,75 \pm 0,96 \mathrm{ab}$ \\
\hline
\end{tabular}

Keterangan : Angka yang diikuti oleh huruf yang sama menunjukkan tidak beda nyata berdasarkan uji DMRT taraf $5 \%$.

Kandungan unsur hara $\mathrm{N}$ cukup tinggi pada pupuk daun dengan jumlah $20 \%$, dan mampu diserap tanaman dengan baik, sehingga dapat memacu pertumbuhan luas daun tanaman kedelai. Peningkatan luas daun akan mengakibatkan indeks luas daun meningkat. Nilai ILD yang tinggi dapat meningkatkan laju fotosintesis sehingga fotosintat yang tersedia juga meningkat, sehingga pertumbuhan dapat optimal. Menurut Brest dan Barack (2009), Semakin besar luas daun maka proses fotosintesis yang berlangsung semakin tinggi. Proses fotosintesis yang tinggi dapat menghasilkan fotosintat yang tinggi. Fotosintat digunakan tanaman untuk memenuhi nutrisi dan disalurkan ke bagian-bagian tanaman untuk melakukan pertumbuhan.

Hasil analisis korelasi antara indeks luas daun (ILD) dengan berbagai parameter hasil memiliki nilai yang berbeda. Nilai koefisien korelasi ILD dengan jumlah polong per tanaman sangat kuat, sementara nilai korelasi ILD dengan berat biji per petak, jumlah biji per polong, dan berat 100 biji lemah dan berkolerasi negatif. Korelasi negatif tidak nyata antara ILD dengan berat 100 biji memiliki arti bahwa semakin tinggi ILD kedelai, tidak selalu diikuti dengan peningkatan berat 100 biji kedelai. Korelasi Ild terhadap berbagai parameter dapat dilihat pada (Tabel 4).

Tabel 4. Korelasi ILD terhadap berbagai parameter hasil Kedelai

\begin{tabular}{llllll}
\hline Korelasi & ILD & $\begin{array}{l}\text { Jumlah } \\
\text { Polong/ } \\
\text { Tanaman }\end{array}$ & $\begin{array}{l}\text { Berat } \\
\text { Biji / } \\
\text { Petak }\end{array}$ & $\begin{array}{l}\text { Jumlah } \\
\text { Biji/ } \\
\text { Polong }\end{array}$ & $\begin{array}{l}\text { Berat } \\
100 \\
\text { Biji }\end{array}$ \\
\hline ILD & 1,000 & & & & \\
JP/tanaman & $0,632^{* *}$ & 1,000 & & & \\
BB/petak & 0,157 & 0,073 & 1,000 & & \\
JB/polong & 0,309 & 0,186 & 0,162 & 1,000 & 1,000 \\
Berat 100 biji & $-0,328$ & $-0,306$ & $-0,118$ & 0,334 & 1,300
\end{tabular}

Keterangan: Data hasil pengamatan dianalisis dengan menggunakan SPSS uji korelasi, ${ }^{* *}=$ Korelasi signifikan pada $\alpha=0.01$ atau tingkat kepercayaan 99\% (2-tailed)

Menurut Adhitya et al. (2015), pertumbuhan vegetatif yang baik, tidak selalu menunjukkan hasil Efektivitas Pupuk Daun terhadap Pertumbuhan dan Hasil Kedelai pada Sistem Tanpa Olah Tanah (Dewi Auliya Ulva, Supriyono, Pardono) 
yang baik, hal tersebut dipengaruhi penyerapan unsur hara tanaman, faktor lingkungan, kelengasan tanah hingga faktor genetik dari tanaman kedelai yang ditanam. Beberapa faktor tersebut dapat mempengaruhi ILD dan tingkat fotosintesis.

Fotosintesis yang baik juga didukung oleh kandungan klorofil pada daun. Kandungan klorofil yang tinggi ditunjukkan dengan warna daun hijau pekat. Pengamatan warna daun dilakukan menggunakan Munsell colour book yang memperlihatkan notasi dan menunjukkan adanya perbedaan tingkat kehijauan warna daun kedelai yang diamati. Notasi warna daun P1 (kontrol) dan P2 (pupuk Gandasil D setiap 10 hari) yaitu 7.5GY 6/4 disimbolkan dalam skor 1-1.5, diartikan memiliki warna hijau kekuningan dengan tingkat kecerahan sedang, dan ketajaman warna sedang.

Pemberian pupuk daun tidak dapat berpengaruh nyata terhadap warna daun kedelai. Notasi warna daun P3 (pupuk Gandasil D setiap 15 hari), P4 (pupuk Gandasil B 10 hari), dan P7 (pupuk Gandasil D dan B setiap 15 hari) adalah 7.5 GY 6/6 disimbolkan dalam skor 1.6-2 diartikan warna daun hijau dengan ketajaman tinggi dan kecerahan tinggi. Notasi warna daun P5 (pupuk daun Gandasil B setiap 15 hari) adalah 7.5 GY 7/8 disimbolkan dalam skor 2.1-2.75 diartikan warna daun hijau pucat, ketajaman rendah, dan kecerahan tinggi. Menurut Setyanti et al. (2013), kandungan nitrogen yang tinggi menjadikan dedaunan lebih hijau, sementara tanaman yang kekurangan nitrogen, memiliki warna daun yang kuning pucat dan hijau kelam. Selain itu, pengukuran batang juga dilakukan untuk mengetahui pertumbuhan keledai. Diameter batang dalam pertumbuhannya membutuhkan unsur hara $\mathrm{N}, \mathrm{P}$ dan $\mathrm{K}$ untuk meningkatkan pertumbuhan diameter batang. Menurut Henri Tamba (2017), pupuk daun yang mengandung $N$, P dan $K$ dapat memacu sel di ujung batang untuk segera mengadakan pembelahan dan pembesaran.

Pemberian pupuk daun tidak berpengaruh nyata terhadap diameter batang kedelai, meskipun tidak ada pengaruh nyata, diameter batang kedelai tetap mengalami peningkatan diameter batang. P3 pupuk daun Gandasil D 15 hari) dan P2 (pupuk daun Gandasil D setiap 10 hari) meunjukkan diameter yang paling besar dibandingkan perlakuan lain. Tidak berpengaruhnya pupuk daun terhadap diameter batang diduga karena kebutuhan unsur hara tidak tercukupi bagi tanaman dan diduga penyerapan unsur hara $\mathrm{N}$ dari pupuk daun ke tanaman lebih banyak tersalurkan pada bagian daun untuk kebutuhan fotosintesis. Menurut Sofyan (2005), semakin besar tanaman, unsur hara yang dibutuhkan juga semakin banyak.

Pengaruh pemberian pupuk daun terhadap variabel hasil juga diamati untuk mengetahui pengaruh pupuk daun terhadap hasil produksi kedelai. Hal tersebut dapat dilihat pada (Tabel 5). Pemberian pupuk daun tidak berpengaruh nyata terhadap berat segar brangkasan kedelai. Tidak adanya pengaruh pupuk daun terhadap berat segar diduga karena tidak tercukupinya kebutuhan unsur hara nitrogen yang dibutuhkan tanaman, dan tidak adanya penyerapan yang baik. Perlakuan P3 (pupuk daun Gandasil D setiap 15 hari sekali) menunjukkan berat segar tertinggi sebesar 17.25 gram.

P3 diduga dapat menyerap unsur hara dengan baik, sehingga kebutuhan unsur hara dapat tercukupi, khususnya unsur hara $\mathrm{N}$. Unsur hara $\mathrm{N}$ berperan penting dalam pertumbuhan tanaman, terutama sebagai unsur pembangun klorofil, lemak, enzim, dan senyawa lainnya. Menurut Fader dan Kohler (2015), pembentukan senyawa dan biomassa tersebut pada tanaman dapat meningkatkan berat segar. Selain itu berat segar tanaman terdiri dari $80-90 \%$ air, dan sisanya adalah berat kering.

Pemberian pupuk daun berpengaruh nyata terhadap berat kering kedelai. Unsur hara yang diserap akar memberi kontribusi terhadap pertambahan berat kering tanaman. P3 (pupuk daun gandasil D setiap 15 hari) menunjukkan rata-rata berat kering paling tinggi yaitu 9.07 gram. Hasil tertinggi pada P3, diduga karena pada fase vegetatif, tanaman dapat menyerap $\mathrm{N}$ dengan baik didukung dengan luas daun yang besar, sehingga dalam berlangsungnya proses fotosintesis, mampu menghasilkan fotosintat yang besar.

Menurut Wawan (2006), berat kering merupakan akumulasi dari berbagai cadangan makanan seperti protein, karbohidrat, dan lipida (lemak) serta akumulasi fotosintat yang berada di batang dan daun. Pupuk daun gandasil D yang diaplikasikan setiap 15 hari sekali dapat memberikan hasil yang baik pada serapan unsur nitrogen didalam daun dan dapat meningkatkan berat kering tanaman kedelai. Selain itu pemberian pupuk daun mampu berpengaruh nyata terhadap hasil jumlah polong/tanaman. Ketersediaan unsur hara yang paling berpengaruh dalam pembentukan polong adalah $P$ dan K. Jumlah polong yang tumbuh pada ketiak daun dapat menunjukkan hasil tanaman tersebut.

Tabel 5. Pengaruh pupuk daun terhadap variabel hasil kedelai (Glycine max L.)

Variabel Pengamatan

\begin{tabular}{|c|c|c|c|c|c|c|c|}
\hline Gamdasil & $\begin{array}{c}\text { Frekuensi } \\
\text { Aplikasi }\end{array}$ & $\begin{array}{c}\text { Berat Segar } \\
\text { (g) }\end{array}$ & $\begin{array}{c}\text { Biomassa } \\
\text { (g) }\end{array}$ & $\begin{array}{l}\text { Jumlah } \\
\text { Polong }\end{array}$ & $\begin{array}{l}\text { Jumlah Biji / } \\
\text { Polong }\end{array}$ & $\begin{array}{l}\text { Berat } 100 \text { Biji } \\
(\mathrm{g})\end{array}$ & $\begin{array}{c}\text { Berat Biji / } \\
\text { Petak }\end{array}$ \\
\hline $\begin{array}{l}\text { Tanpa pupuk } \\
\text { D } \\
\text { D } \\
\text { B } \\
\text { B } \\
\text { D,B } \\
\text { D,B }\end{array}$ & $\begin{array}{l}- \\
10 \text { hari } \\
15 \text { hari } \\
10 \text { hari } \\
15 \text { hari } \\
10 \text { hari } \\
15 \text { hari }\end{array}$ & $\begin{array}{l}11,78 \pm 3,88 \mathrm{abc} \\
14,84 \pm 6,01 \mathrm{bc} \\
17,25 \pm 6,97 \mathrm{c} \\
9,66 \pm 5,18 \mathrm{abc} \\
12,28 \pm 1,92 \mathrm{abc} \\
6,65 \pm 3,73 \mathrm{a} \\
8,50 \pm 0,88 \mathrm{ab}\end{array}$ & $\begin{array}{l}6,10 \pm 1,80 \mathrm{abc} \\
7,67 \pm 3,31 \mathrm{bc} \\
9,07 \pm 1,71 \mathrm{c} \\
5,11 \pm 2,63 \mathrm{ab} \\
6,30 \pm 1,08 \mathrm{abc} \\
3,84 \pm 1,86 \mathrm{a} \\
4,50 \pm 0,70 \mathrm{ab}\end{array}$ & $\begin{array}{c}34,66 \pm 4,38 \mathrm{bc} \\
45,25 \pm 18,56 \mathrm{c} \\
46,83 \pm 5,31 \mathrm{c} \\
26,00 \pm 9,71 \mathrm{ab} \\
16,50 \pm 5,38 \mathrm{a} \\
25,17 \pm 13,88 \mathrm{ab} \\
30,25 \pm 4,11 \mathrm{abc}\end{array}$ & $\begin{array}{l}1,92 \pm 0,10 a b \\
2,10 \pm 0,16 b \\
2,12 \pm 0,07 b \\
2,05 \pm 0,17 b \\
1,88 \pm 0,24 a b \\
2,03 \pm 0,13 a b \\
1,71 \pm 0,29 a \\
\end{array}$ & $\begin{array}{l}17,34 \pm 5,20 \mathrm{a} \\
17,74 \pm 2,29 \mathrm{ab} \\
17,15 \pm 1,64 \mathrm{a} \\
17,80 \pm 1,79 \mathrm{ab} \\
20,56 \pm 1,20 \mathrm{~b} \\
18,50 \pm 2,29 \mathrm{ab} \\
20,73 \pm 1,87 \mathrm{~b}\end{array}$ & $\begin{array}{l}575,15 \pm 10599 \mathrm{~cd} \\
737,23 \pm 118,44 \mathrm{~d} \\
510.68 \pm 5.31 \mathrm{bc} \\
273.60 \pm 9.71 \mathrm{a} \\
185.70 \pm 5.38 \mathrm{a} \\
315.20 \pm 13.88 \mathrm{a} \\
351.98 \pm 4.11 \mathrm{ab}\end{array}$ \\
\hline
\end{tabular}

Keterangan : Angka yang diikuti huruf yang sama menunjukkan tidak beda nyata berdasarkan uji DMRT taraf $5 \%$. 
Ketersediaan unsur hara yang paling berpengaruh dalam pembentukan polong adalah P dan K. P3 (pupuk daun Gandasil D setiap 15 hari) menunjukkan hasil tertinggi yaitu 46.83 gram. Pemberian pupuk daun dengan frekuensi setiap 15 hari sekali mampu mencukupi kebutuhan unsur hara yang dibutuhkan tanaman secara maksimal. Menurut Ghulamahdi et al. (2009), saat pertumbuhan reproduktif tanaman membutuhkan unsur hara $\mathrm{N}, \mathrm{P}$, dan $\mathrm{K}$ yang besar. Menurut Ray et al. (2009), kedelai membutuhkan unsur hara $P$ dalam jumlah banyak, saat tanaman dalam masa pembentukan polong sampai 10 hari sebelum biji berkembang penuh, sementara unsur hara $K$ dibutuhkan dalam jumlah banyak saat pembesaran polong dan pengisian biji. Besar kecilnya polong berpengaruh terhadap berat biji per petak, sehingga dibutuhkan polong yang besar untuk meningkatkan berap biji per petak. Pemberian pupuk daun mampu berpengaruh nyata terhadap hasil berat biji per petak. Berpengaruhnya pupuk daun terhadap berat biji per petak diduga dipengaruhi oleh peran dari kandungan unsur hara yang ada didalam pupuk daun. Berat biji mampu menunjukan seberapa besar peran fotosintesis menghasilkan biji yang baik. Hasil tertinggi ditunjukkan P2 (pupuk daun Gandasil D setiap 10 hari) sebesar 737.23 gram. Hasil terendah ditunjukkan P5 (pupuk daun Gandasil B setiap 15 hari sebesar 185.70 gram. Menurut Wahyu dan Setiyono (2012), kombinasi pupuk yang tepat dapat mempengaruhi tinggi rendahnya berat biji/petak.

Menurut Maruapey (2010), unsur hara N dapat berperan dalam pembentukan asam amino pada saat pembentukan protein biji kedelai, unsur $\mathrm{P}$ berperan dalam metabolisme sel, pembentukan akar dan biji, unsur $\mathrm{K}$ berperan dalam translokasi asimilat. Ketiga pupuk tersebut merupakan unsur hara yang sangat dibutuhkan untuk pertumbuhan dan hasil kedelai. Menurut Burton WJ (2011), fosfat lebih banyak dibutuhkan kedelai untuk mendukung proses metabolisme dan pembentukan biji. Dengan demikian kombinasi perlakuan yang tepat akan dapat meningkatkan pertumbuhan tanaman dan hasil biji kedelai. Peningkatan hasil biji juga dipengaruhi oleh jumlah biji disetiap polongnya.

Pemberian pupuk daun tidak berpengaruh nyata terhadap jumlah biji per polong. Tidak berpengaruhnya pupuk daun terhadap jumlah biji per polong diduga karena tidak adanya keseimbangan pupuk yang baik. Selain itu faktor genetik tanaman mempengaruhi dalam pembentukan biji yang terbentuk. Hal ini sesuai dengan pernyataan Adhitya et al. (2015), yang menyatakan Keseimbangan dalam memberikan suplai unsur hara diperlukan dalam budidaya untuk membantu pertumbuhan tanaman yang baik. Perlakuan P3 (pemberian pupuk daun selama 15 hari sekali) memiliki hasil yang paling tinggi yaitu rata-rata 2.12 biji. Jumlah biji per polong menujukkan banyaknya biji dan hasil kedelai per taanamannya. Menurut Anggraeni (2010), semakin banyak biji terisi maka semakin berat hasilnya. Perlakuan P3 memiliki jumlah biji polong terbanyak, meskipun pemberian pupuk daun tidak mempengaruhi jumlah biji per polong. Menurut Yudhi (2015), mengatakan hasil tanaman yang baik dapat dicapai jika lingkungan yang mempengaruhi pertumbuhan juga berimbang. Sesuai dengan hasil analisis tanah yang dilakukan pada penelitian ini, kandungan unsur hara $P$ dalam tanah sangat tinggi, penambahan unsur hara juga dilakukan melalui pupuk daun, yang hal tersebut diduga dapat menjadi salah satu hal yang mempengaruhi keseimbangan pupuk. Pemberian pupuk daun dapat berpengaruh nyata terhadap berat 100 biji kedelai (tabel 5). P7 (pupuk daun Gandasil D dan $B$ setiap 15 hari) menujukkan hasil terbaik yaitu 20.73 gram. Hasil tertinggi diduga karena tanaman dapat menyerap unsur hara yang diberikan dengan baik, terutama unsur $\mathrm{P}$ dan $\mathrm{K}$. Setiap varietas memiliki perbedaan berat 100 biji yang disebabkan oleh faktor genetik. Menurut Woon (2011), kandungan pupuk P dan $\mathrm{K}$ yang tinggi dalam pupuk daun dapat memacu pembentukan biji selain dari faktor genetik yang mendukung.

\section{KESIMPULAN}

Pemberian pupuk daun Gandasil D setiap 15 hari pada fase vegetatif mampu meningkatkan indeks luas daun sebesar $25,73 \%$, dan pemberian pupuk daun Gandasil B setiap 15 hari pada fase generatif mampu meningkatkan kualitas hasil 100 biji kedelai sebesar $15,96 \%$, namun menurunkan kuantitas berat biji/petak, sehingga pupuk daun tidak efektif diberikan dalam budidaya kedelai pada sistem tanpa olah tanah.

\section{DAFTAR PUSTAKA}

[BPS] Badan Pusat Statistik. 2016. Produksi Kedelai Indonesia 1993-2015. Badan pusat statistik republik indonesia,. Jakarta

Adhitya H, Didik I, Eka W. 2015. Hubungan komponen hasil dan hasil tiga belas kultivar kedelai (Glycine max L.). J Vegetalika 4(3): 14-28

Adnan, Hasanuddin, Manfarizah. 2012. Aplikasi beberapa dosis herbisida glifosfat dan paraquat pada sistem tanpa olah tanah serta pengaruhnya terhadap sifat kimia tanah, karakteristik gulmadan hasil kedelai. J Agrista 16(3): 135-145

Anggraeni. 2010. Kedelai dan permasalahannya. Politeknik Pertanian Press, Jember

Brest dan Barack. 2009. Leaf area index simulation in soybean grown under near-optimal conditions. Field Crops Research. 108 (1): 82-92

Burton WJ. 2011. Soybean (Glycine max L.). Field Crops Research 53(1): 171-186

Fader G dan Kohler. 2015 Seed growth rate and carbohydrate of soybean fruit. Field Plant Physicol 79(3): 663-666

Fiyanti dan Prastiti. 1991. Budidaya kedelai. Penebar Swadaya, Jakarta.

Ghonema dan Okut. 2013. Respon of Soybean to Plant Distributions and Microelements Foliar Spraying. J. of Agriculture Science 28(2):121-128

Ghulamahdi, Sudirman, Sandra. 2009. Produktivitas tiga genotipe kedelai dengan air berbeda dan kedalaman muka air pada berbagai kondisi tanah di pasang surut. J Agronomi Indonesia 44(3): 248-254

Guiterezz, Schiener, Lavado. 2014. Late season nitrogen fertilization of soybean: effect on leaf senescence yield and environment. Nutrient Cycling in Agroecosystems 68(1):109-115. 
Agrosains 21(2): 29-33, 2019; pISSN: 1411-5786; eISSN: 2655 - 7339

Henri T. 2017. Respon pertumbuhan dan produksi kedelai (Glycine max L.) terhadap aplikasi pupuk kandang sapu dan pupuk organik cair. J Agroteknologi 5(2):307-314

Mandie V, Simic A, Bijelic. 2015. Effect of foliar fertilization on soybean grain yield. Biotechnology Husbandary J 31(1):1-12

Maruapey. 2010. Pengaruh pemberian pupuk daun terhadap pertumbuhan dan hasil kedelai (Glycine max L.). J Tanaman Pangan 4(2):81-86

Mastutik S, Yusnaini S, Maria V. 2013. Pengaruh sistem olah tanah dan pemberian mulsa bagas terhadap populasi fungsi mikoriza arbuskula pada perkebunan tebu. J Agrotropika 18(1):16-20

Nasaruddin dan Rosmawati. 2011. Pemberian kombinasi pupuk daun gandasil d dengan pupuk nano silika terhadap pertumbuhan kedelai (Glycine max L.). J Biologi 5(2):38-48

Ray, Heatherly, Fristchi. 2009. Influence of large amounts of nitrogen on nonirrigated and irrigated soybean. Crop Science 46(2):52-60

Sumarno, Manshuri AG 2004. Persyaratan tumbuh dan wilayah produksi kedelai di indonesia. kedelai teknik produksi dan pengembangan. Badan Penelitian dan Pengembangan Pertanian. Pusat Penelitian dan Pengembangan Tanaman Pangan.
Taufika R. 2011. Pengujian beberapa dosis pupuk organik cair terhadap pertumbuhan dan hasil kedelai (Glycine max L.) kabupaten lima puluh koto. J IImu Tanaman2(1):1-10

Wahyu dan Setiyono. 2012. Pengaruh jumlah baris kedelai dan dosis pupuk organik terhadap pertumbuhan dan hasil ubi jalar didtem tumpang sari kedelai-ubi jalar. J Agritop. 16(1): 38-60

Wawan. 2006. Budidaya tanaman kedelai (Glycine max L.). Unpad Press, Bandung.

Woon CK. 2011. Effect pf Foliar Fertilizer on the Growth of Soybean Cultivars. J. of Agro Crop Science 3(1):69-72

Yinbo G, Ineke S, Herman V. 2010. Effect of $n$ fertilizer top dressing at various reproductive stages on growth and yield of three soybean (Glycine max L.) genotypes. Field Crops Research 80:147-155

Zhao L, Xu Yajun, Zheng A. 2017. Antagonic endophytic bacteria associated with nodules of soybean (Glycine max L.) and plant growth promoting properties. J Microbiology 30(1):1-10 